through her research not only challenges the conclusions reached by academics like Stonequist (1937) and his followers that mixed-race individuals were marginal, illadjusted people, but goes on to show that bi-racialism and bi-culturalism made them 'strong people with diverse and positive perspectives on life', better able to function in the multifarious world we all inhabit now.

\section{Yasmin Alibhai-Brown}

\section{Reference}

STONEQUIST, E. v. (1937) The Marginal Man: A Study in Personality and Culture Conflict New York: Russell \& Russell.

\section{Finding Our Way: Rethinking Ecofeminist Politics}

\section{Janet Biehl}

Black Rose Books: Montreal/New York 1993

ISBN $0921689780 £ 11.99 \mathrm{Pbk}$

ISBNO $921689790 £ 23.00 \mathrm{Hbk}$

Nowhere in the world of contemporary theory is there richer ground for leg-pulling than the realm of ecofeminist writing. For some people to be Green is to be truly green and if you want to save the world through espousing the ecofeminist line then you better get used to being accused of political naivety. Ever since Mary Daly acknowledged the help of a spider in the writing of her vast Wickedary I have had a problem with the web of ideas that has spun from ecofeminism. Is she serious? is the question uppermost in my mind when reading anything which falls into the ecofeminist canon. Biehl's work is more respectful in that it does assume the seriousness of ecofeminist theory but respect does not result in a gentle critique. There are no cheap jokes or jibes here but Biehl's view is unambiguous. Ecofeminists have got it wrong.

Biehl analyses the works of a range of feminist writers and theorists which are, for the purposes of this book, lumped together under the umbrella title of ecofeminists. Charlotte Spretnak, Carolyn Merchant and Starhawk are three of those whose work, Biehl concludes, takes us along a path 'toward a narrow parochialism, primitivism, and irrationalism that will ultimately mystify and support the status quo rather than transcend it'.

Biehl's merciless attack on ecofeminist theory begins with an expose of the lack of theoretical rigour in key ecofeminist texts. Facts, she alleges, are valued if they support the ecofeminist world-view, disregarded if they do not. In her view, far from being a radical force for social change, ecofeminism has largely become an exercise in personal transformation. Biehl also highlights the irony of a discourse which while focusing on religion as a locus of patriarchal power seems to be creating 'a religion in its own right' breeding its own hierarchy of shamanesses and priestesses.

Biehl draws on anthropological and archaeological research to back up her criticisms of ecofeminist writing. In response to those ecofeminist writers who suggest that worship of a goddess in some way facilitates a desired non-patriarchal society, Biehl points to some obvious historical exceptions and then asks the obvious questions. Did the worship of a goddess orchestrate early social relations? Or did the social relations in the cultures themselves produce the goddess? This line of questioning leads to a key issue - the role of myth. Ecofeminists, Biehl argues, appear to believe that swapping from god to goddess, in effect changing the content of myths from 'bad ones' to 'good ones' would change social reality.

Many readers would see this as 
the critical point in Biehl's analysis and hope for more exploration of the cultural role of myth. They will be disappointed. Biehl is clearly not interested in taking the poststructuralist route via Barthes, preferring instead to organize her criticism of ecofeminist theory from the lane marked 'social ecology'. Biehl uses Murray Bookchin's 'dialectical naturalism' as an alternative model for defining nature and argues that this theoretical concept allows for the possibility of what all eco-theorists appear to want - a different and less damaging relationship between humanity and the natural world.

Unfortunately, from the moment at which she names her preferred way of theorizing the world Biehl's work loses its critical edge. In reproducing Bookchin's arguments explanation comes perilously close to exultation. Dialectical naturalism, she explains, is an holistic approach which looks at the world as a whole from a developmental perspective. It is a theory of progress which posits a necessary passage from a state of 'potentiality' to that of full development which, in the case of individuals allows for the ultimate destination of self-actualization. One example given is the development of the individual from a state of childhood to a 'fuller more differentiated being'. What this example does not address is the vast debate around the issue of just where the boundaries lie between childhood and adulthood and just what it means to be a 'fuller more differentiated being'.

In fact, the theory of dialectical naturalism seems little more than greenspeak for personal growth. There is an unnerving similarity between Biehl's enthusiastic espousal of Bookchin's theory and the work of ecofeminist writers. Both share a fervent belief in one key set of ideas and while it is often satisfying to be taken in an obvious direction by an author with a set destination in mind, there is a lot to be said for the theory flirt. An author who has not quite settled on a complete explanation for everything but who was willing to engage with a range of ideas may have produced a more satisfying critique of ecofeminist politics.

To be fair, Biehl's project is to rethink rather than just demolish ecofeminism and this she does. Her ultimate desire is clearly stated: to see the elimination of capitalism and the nation-state and the restructuring of society into decentralized, cooperative communities. For Biehl the problem with ecofeminists is not what they aim to do but the way that they do it.

\section{Shelagh Young}

\section{Getting Smart: Feminist Research and Pedagogy With/In the Postmodern}

\section{Patti Lather}

Routledge: New York/London 1991

ISBN $0415903777 £ 35.00 \mathrm{Hbk}$

Research on gender inequality in education and postmodernism has never really clicked. The emphasis on improvement and action in educational research and the orientation of research on the individual learning and development processes of teachers and pupils appear to be at odds with postmodernism. The line of argument inspired by postmodernism of 'gender as a social construction', which has proved fruitful in other areas of women's studies, has scarcely produced any research on gender and educational issues (ten Dam and Volman, 1991). The few exceptions concern smallscale research projects (e.g. Davies, 1989). Patti Lather's Getting Smart qua theme really gets to the heart of the matter. Lather tries to make a connexion between feminism, postmodernism and critical educational theory and considers the conse- 